\title{
Retrato preliminar do território do Alto Sertão Sergipano pelos dados do censo agropecuário 2017
}

\section{Preliminary portrait of the territory of the Alto Sertão Sergipano by the data of Censo Agropecuário 2017}

\section{Retrato preliminar del territorio de las tierras del Alto Sertão Sergipano de los datos de Censo Agropecuário 2017}

\author{
Paulo Henrique Neves Santos ${ }^{1}$ https://orcid.org/0000-0002-3115-469X \\ José Eloizio da Costa ${ }^{2}$ https://orcid.org/0000-0002-3777-5403
}

\footnotetext{
${ }^{1}$ Graduando - Universidade Federal de Sergipe - UFS- São Cristóvão- Sergipe- Brasil ph.federal.ufs@ gmail.com

${ }^{2}$ Doutor em geografia, Professor Titular da Universidade Federal de Sergipe-- São Cristóvão- Sergipe- Brasil, Docente do Programa de Pós-Graduação em Geografia da UFS e do PPGEO-UESB, eloizio.npgeo@gmail.com
}

\section{Resumo}

O conhecimento sobre a dinâmica econômica rural do território brasileiro consiste ponto fundamental num país em que a produção agropecuária se destaca como principal setor econômico e é a principal fonte de sobrevivência de famílias de baixa renda. $\mathrm{O}$ presente artigo consiste em um retrato preliminar sobre o espaço rural baseado nos dados do censo agropecuário realizado em 2017-2018, limitando-se ao recorte espacial do Território de Planejamento do Alto Sertão de Sergipe. Para realização de tal estudo, foram selecianadas tabelas especificas disponíveis pelo Sidra - Censo agropecuário, utilizando-se variáveis que representassem o quadro geral da área de estudo, relacionadas especialmente a estrutura fundiária, lavouras temporárias e permanentes e a produção pecuária.

Palavras-chave: Alto sertão sergipano. Censo agropecuário. Agricultura familiar.

\begin{abstract}
Knowledge about rural economic dynamics of brasilian territory consists of a fundamental point in a country where agricultural production stands out as the main economic sector and the main source of survival for low-income families. This article consists of a preliminary portrait of rural space based in censo agropecuario data realized in 2017-2018. The spacial cutout is limited in Território de Planejamento do Alto Sertão de Sergipe. For this production, was selected specific tables available in Sidra - Censo agropecuário. Using the variables that represent a general picture of the studied area, relating especially of land structure, temporary and permanent tillage, and livestock production.
\end{abstract}


Keywords: Alto Sertão Sergipano. Agricultural census. Family farming.

\section{Resumen}

El conocimiento sobre la dinámica económica rural del territorio brasileño es un punto fundamental en un país en que la producción agrícola se destaca como el principal sector económico y es la principal fuente de supervivencia para las familias de bajos ingresos. Este artículo consiste en un retrato preliminar del espacio rural basado en datos del censo agropecuário realizado en 2017-2018, limitado al recorte espacial de lo Território de Planejamento do Alto Sertão de Sergipe. Para llevar a cabo dicho estudio, tablas específicas disponibles por el Sidra - Censo agropecuário, utilizando variables que representaban el marco general del área de estudio, especialmente relacionadas con la estructura de la tierra, los cultivos temporales y permanentes y la producción ganadera.

Palabras clave: Alto Sertão Sergipano. Censo agropecuário. Agricultura familiar

\section{Introdução}

O Censo Agropecuário é a mais importante fonte de dados secundários que retratam a dinâmica do mundo rural brasileiro, face a diversidade das variáveis trabalhadas e da possibilidade de construção de indicadores. A construção do Censo de 2017 operou pelos procedimentos tradicionais: a realização da contratação temporária de agentes censitários em diversas funções, sob a responsabilidade do vetusto Instituto Brasileiro de Geografia e Estatística (IBGE) com atribuição institucional de execução do trabalho a partir da figura dos estabelecimentos agropecuários, realizado em um período determinado, denominado de "período de referência".

Para o IBGE, estabelecimento agropecuário é:

Toda unidade de produção/exploração dedicada, total ou parcialmente, a atividades agropecuárias, florestais e aquícolas, independentemente de seu tamanho, de sua forma jurídica (se pertence a um produtor, a vários produtores, a uma empresa, a um conjunto de empresas etc.), ou de sua localização (área urbana ou rural), tendo como objetivo a produção, seja para venda (comercialização da produção) ou para subsistência (sustento do produtor ou de sua família) (IBGE, 2018, p. 17).

O período de referência consiste em intervalo de tempo estabelecido previamente para a padronização das informações coletadas em campo e ter efeito comparativo. A adoção de um período é necessária diante da variabilidade espaço-temporal da produção agropecuária no território nacional. Desse modo, grande parte das perguntas contidas no questionário são direcionadas nas diversas variáveis, envolvendo, entre outras, a questão da produção, 
quantidade produzida, área colhida, efetivo de animais, venda ou beneficiamento de qualquer tipo de lavoura (temporária ou permanente), etc. No caso do Censo Agropecuário de 2017, o período de referência aplicado compreendeu entre $1^{\circ}$ de outubro de 2016 a 30 de setembro de 2017, diferente do período de referência do último censo (2006), que abrangeu o período convencional (01 de janeiro a 31 de dezembro).

É relevante destacar que os dados compilados através do questionário não são definidos pelos recenseadores ou por técnicos contratados, havendo necessidade de aperfeiçoar suas técnicas de trabalho de campo, único procedimento metodológico de obtenção dos dados. Destarte, as informações devem ser de caráter declaratório, ou seja, os produtores são os responsáveis pela fidelidade dos dados que eles mesmos declaram aos recenseadores em campo, mas que também depende da maneira como os recenseadores procedem no momento da aplicação dos questionários. A avaliação final ocorre de baixo para cima na escala estabelecida para o desenho do censo: recenseador, agente censitário supervisor, agente censitário municipal, agente censitário regional, como afirma DELGROSSI (2019), "uma observação importante a ser esclarecida é que as informações registradas nos Censos Agropecuários são declaratórias, prestadas pelo entrevistado no momento da visita."

Portanto, a publicação do Censo Agropecuário de 2017, com os resultados definitivos, em outubro de 2019, mostra um quadro de mudanças na organização e funcionamento dos estabelecimentos agropecuários, inclusive aplicando-se algumas variáveis e indicadores ainda não trabalhados nos censos anteriores, a exemplo do estabelecimento agropecuário em áreas não continuas, ou daqueles oriundos de assentamentos de reforma agrária, inserido como “terras concedidas por órgão fundiário, ainda sem título definitivo". Nesse contexto, é que recortou-se o Território do Alto Sertão Sergipano como objeto de análise a partir dos dados definitivos do Censo de 2017, acompanhando o modelo dos chamados Territórios de Planejamento do Governo do Estado de Sergipe, portanto diferente do modelo adotado pelo IBGE, como as chamadas "regiões geográficas imediatas" que corresponde a região de Nossa Senhora da Glória/SE.

Em Sergipe foram garimpados 93.275 estabelecimentos agropecuários, dos quais 14.756 estão localizados no Território de Planejamento do Alto Sertão Sergipano $(15,8 \%$ em relação ao total), formada por sete municípios, sendo os seguintes: Canindé de São Francisco, Gararu, Monte Alegre de Sergipe, Nossa Senhora da Glória, Nossa Senhora de Lourdes, Poço Redondo e Porto da Folha, como representado no Mapa 1. Foram estes os municípios selecionados para 
realizar o retrato territorial a partir dos dados disponíveis do Censo da agricultura brasileira e que consideramos sob o mesmo rotulo institucional desse território.

Em linhas gerais, no Alto Sertão Sergipano as condições climáticas são descritas como "semiárido brando e mediano com seis a oito meses secos, as chuvas geralmente se iniciam em abril, com períodos secundários em julho" (ARAÚJO, 2012, p.26). Com variação pluviométrica de 00 a $700 \mathrm{~mm} / \mathrm{ano}$, este território passa por períodos de estiagem, que por vezes se estendem de 2 a 3 anos, com impactos devastadores nas atividades agropecuárias, além de seus dissabores ambientais.

Mapa 1: Municípios do Alto Sertão Sergipano

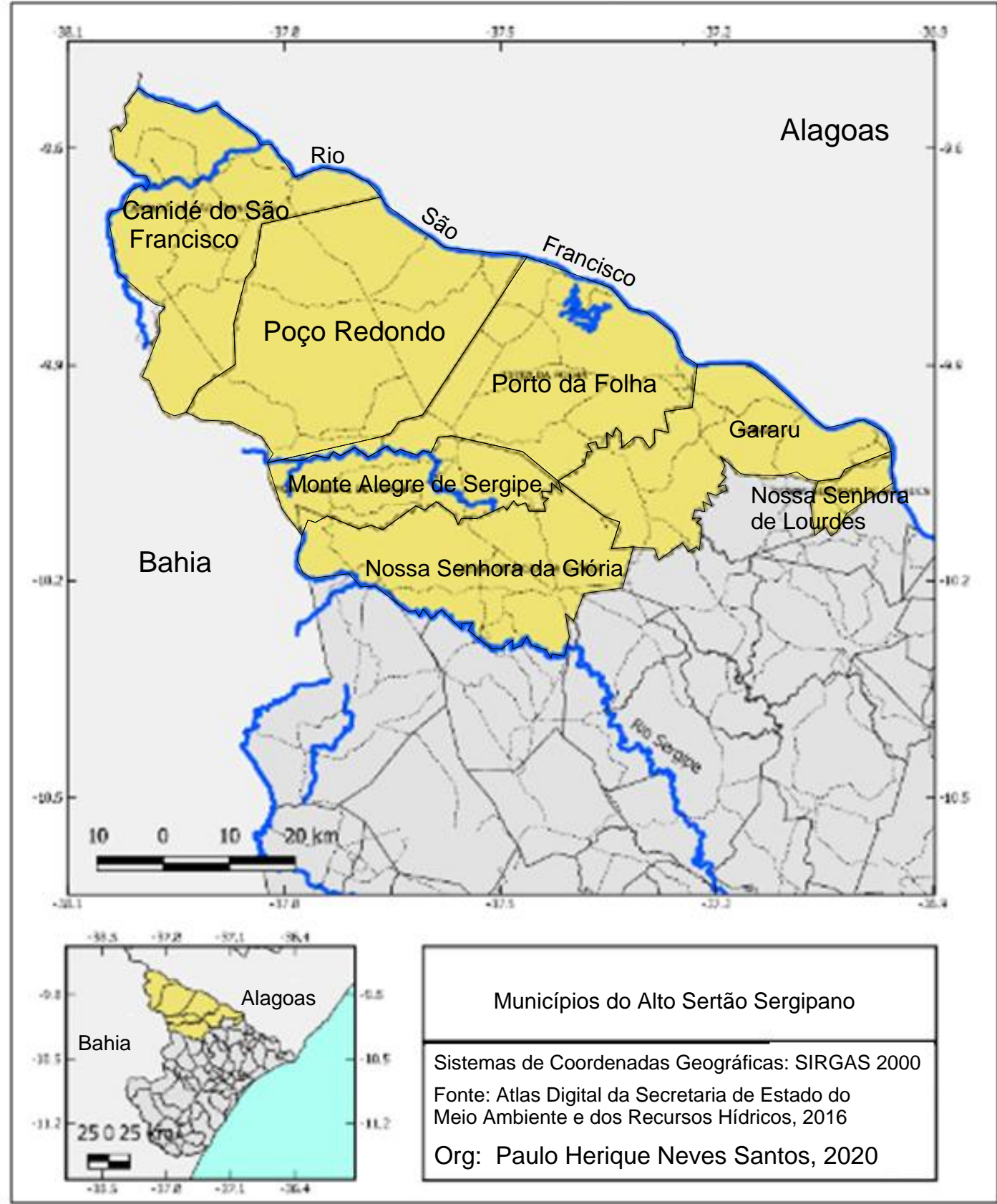

Fonte: Atlas Digital da Secretaria de Estado do Meio Ambiente e dos Recursos Hídricos, 2016. Org: Autores. 2020.

Geopauta, Vitória da Conquista ISSN: 2594-5033, V. 4, n. 3, 2020, p.(153-179) http://periodicos2.uesb.br/index.php/geo, 
Esse quadro climático do território é explicado tanto por fatores internos, como também por externos: os internos - localização em baixa latitude, alta reflexibilidade da crosta terrestre reduzindo a absorção da energia solar, posição geográfica em relação à costa por se tratar de uma área mais interiorana, pouca influência sobre a maritimidade, como fator essencial na determinação da precipitação; e os externos explicado principalmente pelo fenômeno de El Niño, responsável pelas variações da pressão atmosférica (ARAÚJO, 2012, p.26).

As condições climáticas da "região do semiárido" do Alto Sertão Sergipano não favorecem as atividades agropecuárias de relativo valor agregado, sendo necessária à inserção de tecnologias para viabilizar ganhos de produtividade. Entretanto, face ao perfil da baixa renda da maior parte dos agricultores residentes no território, a implementação de equipamentos e técnicas aplicadas ao processo de produção que possa viabilizar ganhos nos sistemas produtivos, torna-se um procedimento impossível sem o apoio de programas e políticas governamentais.

Estes fatores conferem ao território apenas a constituição de um cenário de sistemas produtivos concentrados nas lavouras temporárias adaptadas ao clima, com reduzido regime pluviométrico e centralizados em poucos meses do ano, a exemplo da palma forrageira, macaxeira (aipim), feijão, entre outros. Deve-se destacar que essa produção não tem como principal destinação a comercialização, mas sim, consolida-se enquanto produção para complementar a alimentação familiar, para autoconsumo ou destinadas a venda direta nas feiras municipais ou nos supermercados regionais para a compra de outros alimentos para consumo familiar. Destaca-se a importância da pecuária, esta, talvez, seja a atividade central na geração de emprego e renda entre pequenos agricultores familiares sertanejos, refletidas principalmente na expansão da produção do leite de vaca.

Um dos destaques é a palma forrageira, que apresenta volume produzido expressivo no Território, mas que mantém pequeno volume vendido. Nestes termos, face à escassez da pastagem natural e de alimentos para o rebanho bovino no território, a palma forrageira destaca-se como elemento essencial para complementar a alimentação do efetivo de bovinos nos estabelecimentos agropecuários, onde, segundo os dados do censo agropecuário de 2017, a palma forrageira alcançou a produção de 394.141 toneladas e foram vendidas apenas 14.704 $(3,7 \%)$ toneladas (Gráfico 1). Dessa forma, a irrelevância do volume vendido da palma forrageira pode estar relacionada pelo autoconsumo desse produto, servindo como estratégia na alimentação animal, principalmente entre os agricultores familiares, face a resistência do 
produto as adversidades climáticas, o alto rendimento por área plantada, apesar do alto custo no processo produtivo.

Gráfico 1- Alto Sertão de Sergipe - Volume Produzido e Vendido da Palma Forrageira (em Ton.) - 2017

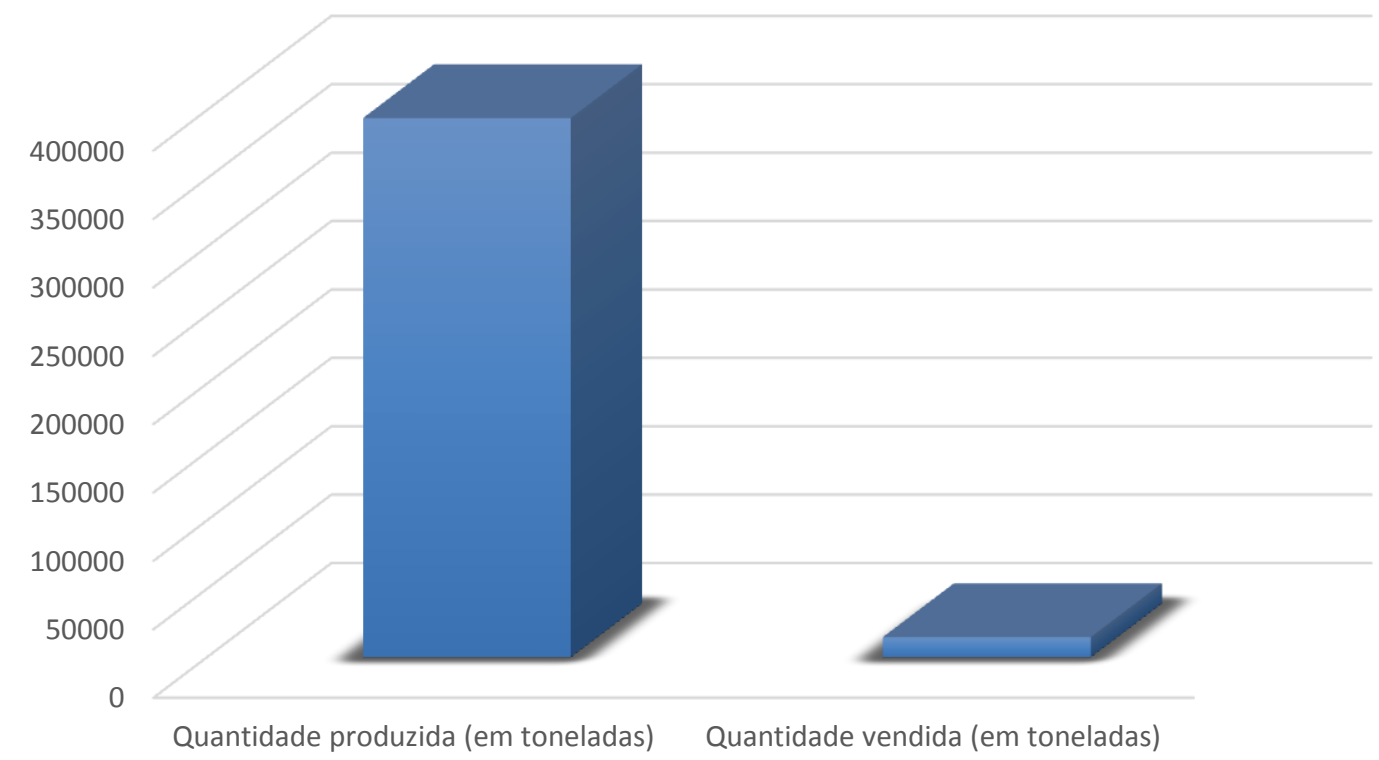

Fonte: IBGE, Censo Agropecuário, 2017. Org: Autores. 2020.

O território do Alto Sertão Sergipano tem um contexto histórico-econômico que se processa em torno da agropecuária e, mais recentemente, com forte potencial na geração de energia renovável e do turismo de lazer. Em termos gerais, no estado de Sergipe observa-se forte concentração da riqueza e renda na região da Grande Aracaju, em contraposição à fragilidade econômica das áreas do interior, particularmente dos territórios de base rural.

No quadro apresentado pelo Plano de Desenvolvimento Regional do Estado de Sergipe (PDR-SE/2017), o segmento da agropecuária representa insignificantes 5\% do PIB, contudo, é um setor de inclusão socio-produtiva para atores sociais de baixa renda nos territórios de base rural. Para efeito, inserimos a dicção que consta no documento institucional:

[...] a agropecuária aparece com participação considerada baixa na composição do PIB estadual, de cerca de 5\% (cinco por cento), porém, com grande importância para a inclusão produtiva da população de baixa renda nas cidades interioranas. (MUÑOZ, et al, 2017).

Os produtores ou famílias de produtores que representam a população de baixa renda no meio rural sergipano e que não integram a dinâmica econômica concentrada na região da Grande Aracaju, é que geralmente estão identificados na categoria de agricultores familiares, como as disposições normativas insculpidas na Lei $\mathrm{n}^{\mathrm{o}} 11.326 / 06$. E posteriormente 
regulamentada pelo Decreto Federal $\mathrm{n}^{\circ}$ 9.064/17, o qual normatiza critérios para ser juridicamente enquadrado como agricultor familiar, tais como, que tenha posse ou domínio de área de até quatro módulos fiscais, do uso exclusivo do trabalho familiar no processo de trabalho, que a renda venha dominantemente da atividade agropecuária e que a gestão da unidade produtivas tenha base familiar $\left(\operatorname{art} .3^{\circ}\right)$.

Destarte, do total dos estabelecimentos agropecuários existentes no Alto Sertão Sergipano, 84\% estão classificados, na condição de produtor, como proprietário, sendo em sua esmagadora maioria inseridos como agricultores familiares. Ainda mais que as unidades consideradas não-familiares integram como aquelas onde o agronegócio é operacionalizado, atuando, mesmo que marginalmente no desenvolvimento das lavouras temporárias de alto rendimento por área, evidentemente destacando-se a cultura do milho para fins de consumo animal.

Nestas linhas, o presente artigo tem como objetivo apresentar o retrato, mesmo que parcial, do espaço rural do Alto Sertão Sergipano a partir dos dados (com suas variáveis e indicadores) do Censo Agropecuário de 2017, especialmente sobre o quadro da agricultura familiar, destacando o volume absoluto da produção e venda da lavoura temporária, bem como da lavoura permanente e da pecuária, visando constituir esse retrato preliminar do mundo rural sergipano.

O artigo encontra-se seccionado em duas partes: na primeira onde são apresentados dados gerais sobre a área de estudo, com dados quantitativos entre os municípios; e na segunda parte onde os municípios estão segmentados e são apresentados dados individuais, especialmente sobre tipo de produção dominante, da agricultura familiar, lavoura temporária e pecuária.

\section{Procedimentos metodológicos e método}

Para a construção do artigo em tela foram utilizados os dados do censo agropecuário realizado institucionalmente pelo Instituto Brasileiro de Geografia e Estatística entre os anos de 2016 e 2017, com uso de variáveis e indicadores mais significativos.

A caracterização socioeconômica da área de estudo baseou-se na leitura do referencial bibliográfico escolhido, especialmente extraído do Anuário Socioeconômico de Sergipe dos anos de 2017 e 2019, organizado pelo Grupo de Pesquisa em Análise de Dados Econômicos do Departamento de Economia da Universidade Federal de Sergipe. 
Para a empreitada, foram utilizadas as tabelas numeradas com dados disponibilizados pelo SIDRA do referido Censo Agropecuário, destacando as seguintes tabelas e respectivos intitulamentos: 1 - Tabela 6778 - Número de estabelecimentos agropecuários, por tipologia, existência de energia elétrica, condição do produtor em relação às terras, residência da pessoa que dirige o estabelecimento, grupos de atividade econômica e grupos de área total; 2 - Tabela 6780 - Número de estabelecimentos agropecuários, por tipologia, origem da orientação técnica recebida, grupos de atividade econômica e grupos de área total; 3 - Tabela 6958 - Produção, Valor da produção, Venda, Valor da venda e Área colhida da lavoura temporária nos estabelecimentos agropecuários, por tipologia, produtos da lavoura temporária, tipo de semente e grupos de área colhida; 4 - Tabela 6910 - Número de estabelecimentos agropecuários com bovinos, Efetivos e Venda, por tipologia, condição do produtor em relação às terras, grupos de cabeças de bovinos e grupos de atividade econômica; 5 - Tabela 6957 - Produção, Valor da produção, Venda, Valor da venda e Área colhida da lavoura temporária nos estabelecimentos agropecuários, por tipologia, produtos da lavoura temporária, condição do produtor em relação às terras e grupos de atividade econômica; 6 - Tabela 6913 - Número de estabelecimentos agropecuários que produziram leite de vaca, Vacas ordenhadas nos estabelecimentos agropecuários, Quantidade produzida de leite de vaca, Valor da produção de leite de vaca; 7 Tabela 6913 - Número de estabelecimentos agropecuários que venderam leite de vaca cru, Quantidade vendida de leite de vaca cru e Valor da venda de leite de vaca cru, por tipologia, grupos de atividade econômica e grupos de área total; 8 - Tabela 6959 - Produção, Valor da produção, Venda, Valor da venda e Área colhida da lavoura temporária nos estabelecimentos agropecuários, por tipologia, produtos da lavoura temporária e grupos de área total

É pertinente observar que estas tabelas permitem realizar cruzamentos de variáveis visando construir indicadores, e que tem como sistema central o número de estabelecimentos agropecuários, além do modelo tipológico previamente estabelecido (agricultura familiar, não familiar, Pronaf B, agricultura familiar não pronafiano, etc). Os dados foram disponibilizados no modelo matricial e reorganizados no software Excel para os interesses desse estudo, onde foram construídas as tabelas e gráficos utilizados.

Os dados selecionados foram exportados e acrescido nos atributos dos dados vetoriais correspondentes a cada município para a produção dos mapas temáticos no software Quantum Gis 3.4. No Mapa 2: Distribuição espacial dos estabelecimentos agropecuários por município, foi utilizada a simbologia de graduação, utilizando a variável "número de estabelecimentos agropecuários" hierarquizado do maior para o menor. 
Quanto ao método aplicou-se o descritivo valorando os dados empíricos e realizando a combinação entre as diversas variáveis disponíveis nas diversas tabelas, além da tentativa de realizar alguma análise, mesmo em caráter preliminar.

\section{Resultados e discussões}

Pelos dados do Censo Agropecuário, em 2017 havia um total de 14.756 Estabelecimentos Agropecuários no Território do Alto Sertão Sergipano (Tabela 1), representando $15,8 \%$ do total do estado. No Território, a maior parte dos estabelecimentos estão concentrados nos municípios de Poço Redondo (27,6\%), seguido por Nossa Senhora da Glória (20,3\%), Porto da Folha (17,9\%) e Gararu (15,3\%), correspondendo por mais de $80 \%$ dos estabelecimentos agropecuários existentes no território, conforme demonstrado no Mapa 2.

Mapa 2- Território do Alto Sertão Sergipano - Distribuição espacial dos estabelecimentos agropecuários por município - 2020.

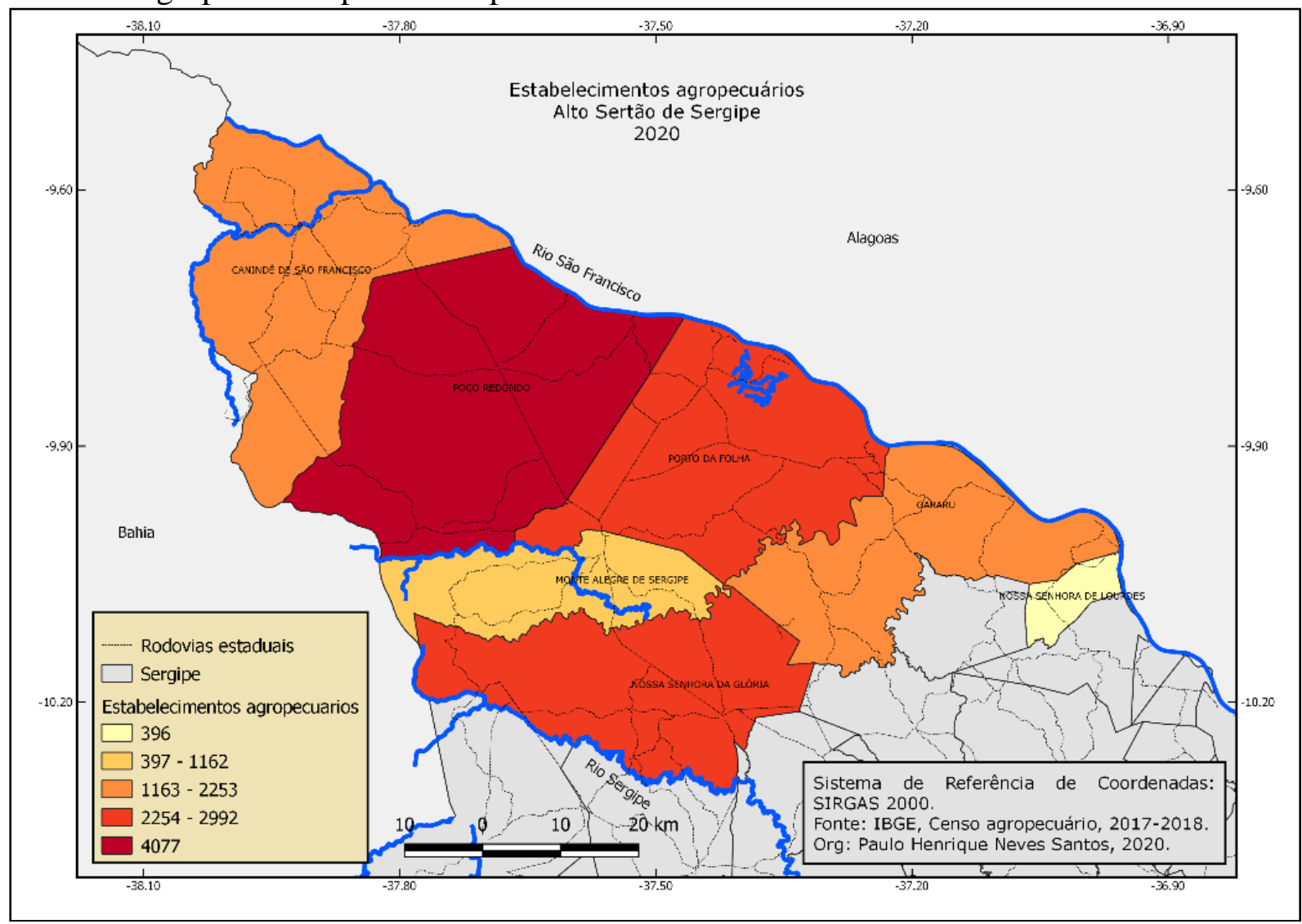

Fonte: IBGE, Censo agropecuário, 2017. Org: Autores. 2020.

Tabela 1- Alto Sertão Sergipano - Número de Estabelecimentos Agropecuários, por município $-2017$. 
AUTOR

\begin{tabular}{l|c}
\hline \multicolumn{1}{c|}{ Municípios } & Total \\
\hline Canindé de São Francisco & 1.229 \\
\hline Gararu & 2.253 \\
\hline Monte Alegre de Sergipe & 1.162 \\
\hline Nossa Senhora da Glória & 2.992 \\
\hline Nossa Senhora de Lourdes & 396 \\
\hline Poço Redondo & 4.077 \\
\hline Porto da Folha & 2.647 \\
\hline Total do Território & 14.756 \\
\hline Sergipe & 93.275 \\
\hline
\end{tabular}

Fonte: IBGE, Censo Agropecuário, 2017. Org: Autores. 2020.

Do total dos estabelecimentos agropecuários do Alto Sertão Sergipano, 88,6\% são enquadrados como de agricultura familiar. Em contrapartida, foram declarados um total de $1.679(11,4 \%)$ como não sendo da agricultura familiar (Gráfico 2).

Gráfico 2- Alto Sertão Sergipano - Participação dos estabelecimentos agropecuários da agricultura familiar e não familiar (em \%) - 2017

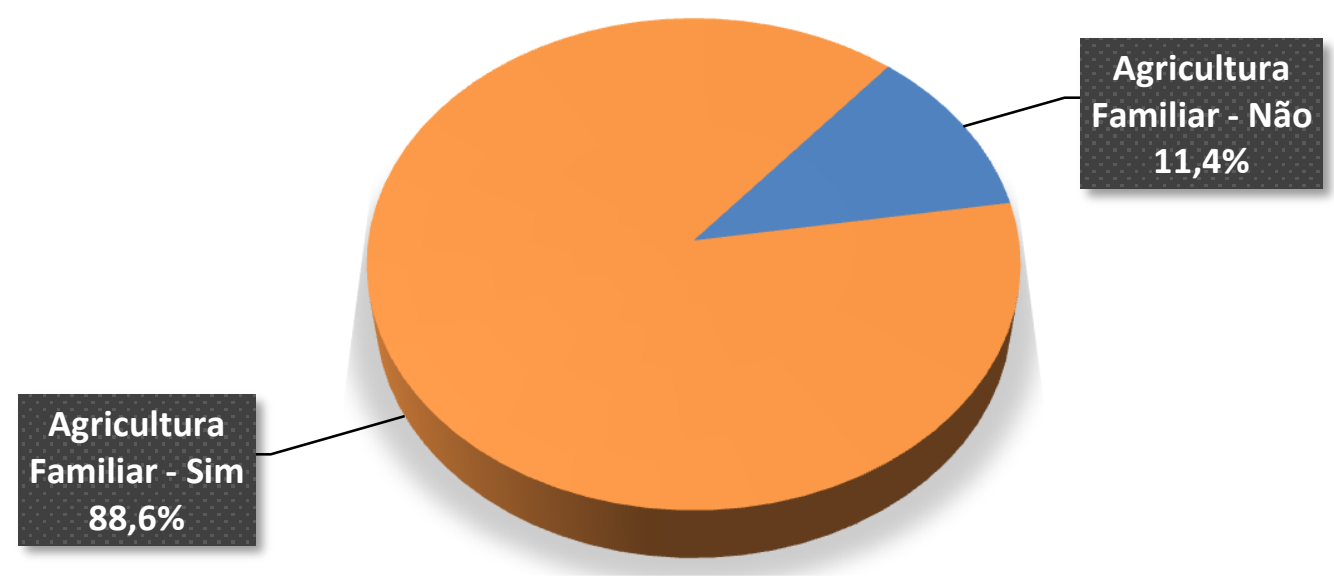

Fonte: IBGE, Censo agropecuário, 2017. Org: Autores. 2020.

Em relação ao acesso à orientação técnica e extensão rural (ATER), tanto no formato público como também no privado, no Território do Alto Sertão Sergipano, apenas 10,9\% dos estabelecimentos agropecuário tiveram acesso, isso em relação ao total do território (Tabela 2), mostrando a fragilidade dessa importante política de ação do Estado destinada principalmente aos agricultores familiares. A ATER tem importância no processo de desenvolvimento rural, e o baixo apoio relaciona-se pelo desmonte dessa política que se arrasta por mais de três décadas e com reflexos destrutivos em ganhos de produtividade, que associados, ao baixo nível de tecnologia, aufere um quadro preocupante para os próximos anos no que refere, por exemplo, ao futuro da agricultura familiar no semiárido sergipano. 
Tabela 2- Território do Alto Sertão Sergipano - Número de estabelecimentos Agropecuários que recebem Assistência Técnica e Extensão Rural, por município. 2017.

\begin{tabular}{l|c}
\hline \multicolumn{1}{c|}{ Município } & Total \\
\hline Canindé de São Francisco (SE) & 158 \\
\hline Gararu (SE) & 131 \\
\hline Monte Alegre de Sergipe (SE) & 73 \\
\hline Nossa Senhora da Glória (SE) & 396 \\
\hline Nossa Senhora de Lourdes (SE) & 13 \\
\hline Poço Redondo (SE) & 638 \\
\hline Porto da Folha (SE) & 206 \\
\hline Total & 1.615 \\
\hline
\end{tabular}

Fonte: IBGE, Censo Agropecuário, 2017. Org: Autores. 2020.

Em relação a pecuária no Território de Planejamento do Alto Sertão de Sergipe, essa atividade é relevante, não apenas pela tradição regional neste segmento, mas pelas mudanças qualitativas observadas na última década, como o aperfeiçoamento no manejo (alimentação e melhoramento genético) e com ele no crescimento dos ganhos de produtividade, face ao ganho de peso do rebanho.

Mapa 3- Alto Sertão Sergipano - Total de bovinos vendidos no período de referência por município.

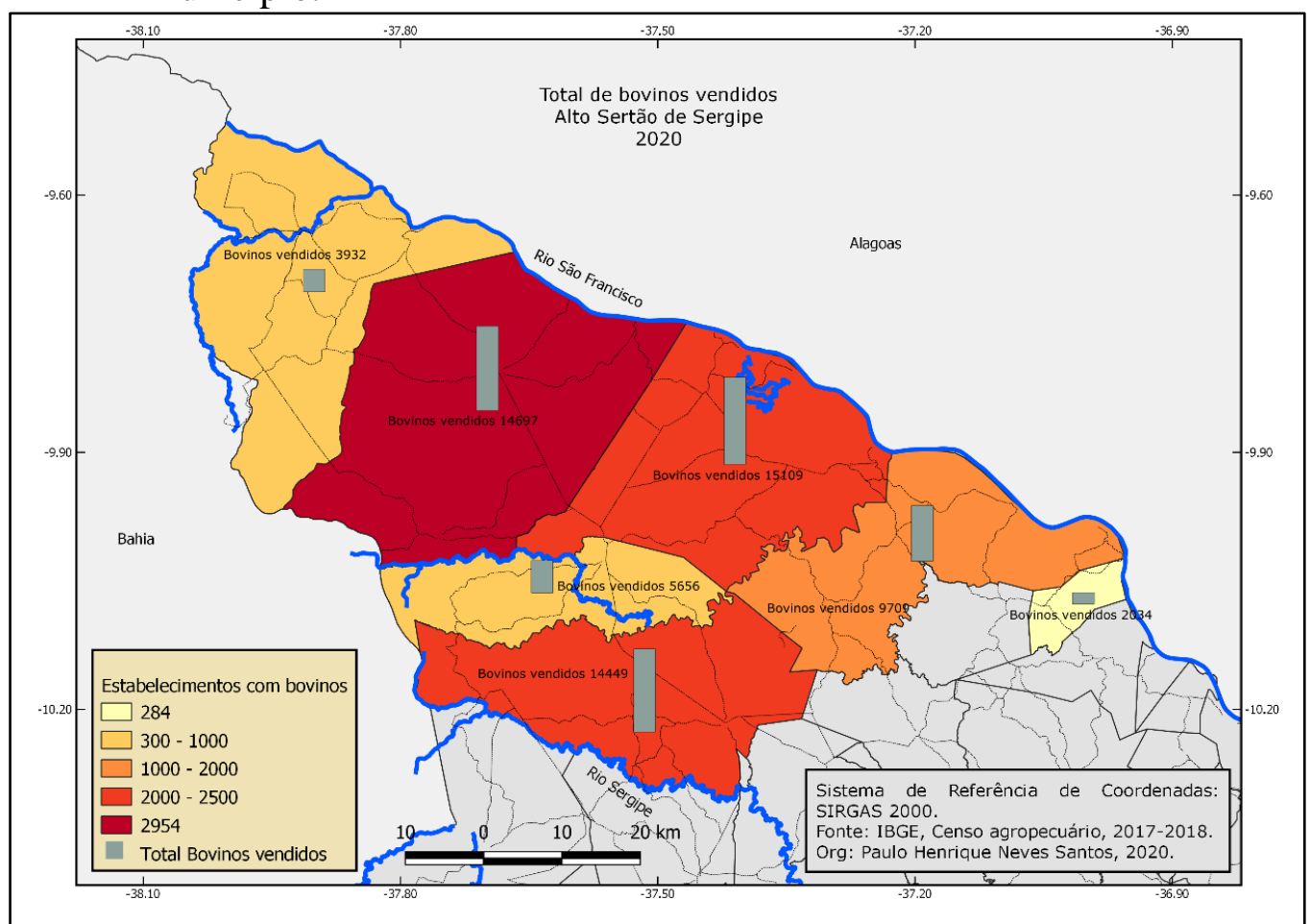

Fonte: IBGE, Censo Agropecuário, 2017. Org: Autores. 2020.

Neste tópico, destaca-se a questão do rebanho bovino vendido em estabelecimentos com até 50 cabeças, em que foram destacados os municípios de Poço Redondo e Porto da Folha, como aqueles que mais registraram venda no período de referência de apuração do censo. Em 
estabelecimentos com mais de 50 cabeças (bovinos), Poço Redondo e Porto da Folha também foram destaques, observando que predominam também na venda de matrizes e reprodutores, visto que na venda de bovinos para cria, recria ou engorda de bovinos vendidos para o abate, Nossa Senhora da Glória apresenta números relevantes (Tabela 3), o que garante a proximidade no valor do total de bovinos vendidos entre os 3 municípios em destaque (Mapa 3).

Tabela 3- Alto Sertão Sergipano - Quantitativo de bovinos vendidos e valor total da venda por município

\begin{tabular}{|c|c|c|c|c|c|c|c|c|c|c|}
\hline \multirow[t]{2}{*}{ Município } & \multicolumn{2}{|c|}{$\begin{array}{c}\text { Estabelecimentos } \\
\text { agropecuários com até } \\
50 \text { bovinos }\end{array}$} & \multicolumn{8}{|c|}{ Estabelecimentos agropecuários com mais de 50 bovinos } \\
\hline & $\begin{array}{l}\text { Número de } \\
\text { bovinos } \\
\text { vendidos } \\
\text { (cabeças) }\end{array}$ & $\begin{array}{c}\text { Valor } \\
\text { total (mil } \\
\text { reais) }\end{array}$ & $\begin{array}{l}\text { Número de } \\
\text { matrizes e } \\
\text { reprodutores } \\
\text { vendidos } \\
\text { (cabeças) }\end{array}$ & $\begin{array}{l}\text { Valor } \\
\text { total (mil } \\
\text { reais) }\end{array}$ & $\begin{array}{l}\text { Número de } \\
\text { bovinos para } \\
\text { cria, recria ou } \\
\text { engorda } \\
\text { vendidos } \\
\text { (cabeças) }\end{array}$ & $\begin{array}{l}\text { Valor } \\
\text { total } \\
\text { (mil } \\
\text { reais) }\end{array}$ & $\begin{array}{c}\text { Número de } \\
\text { bovinos } \\
\text { vendidos para } \\
\text { o abate } \\
\text { (cabeças) }\end{array}$ & $\begin{array}{l}\text { Valor } \\
\text { total (mil } \\
\text { reais) }\end{array}$ & $\begin{array}{l}\text { Total } \\
\text { bovinos } \\
\text { vendidos } \\
\text { (cabeças) }\end{array}$ & $\begin{array}{l}\text { Valor } \\
\text { total (mil } \\
\text { reais) }\end{array}$ \\
\hline $\begin{array}{c}\text { Canindé de São } \\
\text { Francisco }\end{array}$ & 2574 & 3058 & 302 & 635 & 101 & 109 & 955 & 1691 & 3932 & 5493 \\
\hline Gararu & 8130 & 9085 & 325 & 513 & 807 & 914 & 447 & 728 & 9709 & 11240 \\
\hline $\begin{array}{c}\text { Monte Alegre } \\
\text { de Sergipe }\end{array}$ & 3494 & 5447 & 342 & 996 & 1396 & 1489 & 424 & 740 & 5656 & 8672 \\
\hline $\begin{array}{c}\text { Nossa Senhora } \\
\text { da Glória }\end{array}$ & 7533 & 8959 & 628 & 1324 & 2685 & 3760 & 3603 & 9265 & 14449 & 23308 \\
\hline $\begin{array}{c}\text { Nossa Senhora } \\
\text { de Lourdes }\end{array}$ & 1442 & 1554 & 37 & 67 & 381 & 198 & 174 & 266 & 2034 & 2085 \\
\hline Poço Redondo & 12146 & 13018 & 869 & 2286 & 412 & 461 & 1270 & 2197 & 14697 & 17962 \\
\hline Porto da Folha & 12956 & 17740 & 904 & 1943 & 654 & 711 & 595 & 1125 & 15109 & 21519 \\
\hline Total & 48275 & 58861 & 3407 & 7764 & 6436 & 7642 & 7468 & 16012 & 65586 & 90279 \\
\hline
\end{tabular}

Fonte: IBGE, Censo agropecuário, 2017. Org: Autores. 2020.

Como um dos principais derivados do rebanho bovino, $o$ leite de vaca representa a mais importante fonte de renda no Alto Sertão Sergipano, predominando entre os estabelecimentos da agricultura familiar, como pode-se observar na Tabela 4. Os dados dispostos na tabela mostram a relevância da agricultura familiar em todos os municípios do território, onde o leite de vaca está presente em 93,4\% destes estabelecimentos, mostrando o aspecto tradicional da pequena produção familiar em um território socialmente pobre e que o leite se transformou como meio de reprodução do trabalho e da vida desses agricultores.

Do ponto de vista da produção do leite de vaca no período de referência do Censo, foram produzidos 169.834 mil litros no território, dos quais destes foram vendidos 155.019 mil litros, representando 91,3\% em relação a quantidade produzida (Tabelas 5 e 6, por município). É pertinente, mais uma vez, observar que as unidades consideradas como de agricultura familiar foram as principais produtoras de leite de vaca, representando 77,0\% na produção do território, e no segmento do leite de vaca vendido representou 78,7\% do total comercializado no Alto Sertão Sergipano, o que dá o caráter mercantil desse importante setor da economia 
rural sergipana. É evidente que estudos mais detalhados devem ser aprofundados na medida em que formou-se, principalmente nesse território, cadeias de comercialização articuladas com segmentos operacionais com base no beneficiamento e processamento do leite, secundarizando a venda avulsa individualizada, bem tradicional no território. Assim, entre os municípios, a maior parte da produção é destinada a venda (Mapa 4).

Tabela 4- Alto Sertão Sergipano - Número de Estabelecimentos Agropecuários com produção que Produzem Leite de Vaca, na Agricultura Familiar e Não Familiar, por Município - 2017.

\begin{tabular}{l|c|c|c}
\hline \multicolumn{1}{c|}{ Município } & Agricultura Familiar - Sim & Agricultura Familiar - Não & Total \\
\hline Canindé de São Francisco & 546 & 41 & 587 \\
\hline Gararu & 1.245 & 98 & 1.343 \\
\hline Monte alegre de Sergipe & 802 & 62 & 864 \\
\hline Nossa senhora da Glória & 1.558 & 113 & 1.671 \\
\hline Nossa senhora de Lourdes & 198 & 26 & 224 \\
\hline Poço redondo & 2.261 & 125 & 2.386 \\
\hline Porto da folha & 1.654 & 119 & 1.773 \\
\hline \multicolumn{1}{c|}{ Total } & 8.264 & 584 &
\end{tabular}

Fonte: IBGE, Censo Agropecuário, 2017. Org: Autores. 2020.

Tabela 5- Alto Sertão Sergipano - Quantidade Produzida de Leite de Vaca (em mil litros), na Agricultura Familiar e Não Familiar, Por Município - 2017.

\begin{tabular}{l|c|c|c}
\hline Município & \multicolumn{3}{c}{ Quantidade Produzida De Leite De Vaca (Mil Litros) } \\
\hline Canindé De São Francisco & Agricultura Familiar - Sim & Agricultura Familiar - Não & Total \\
\hline Gararu & 7.207 & 4.551 & 11.758 \\
\hline Monte Alegre De Sergipe & 16.902 & 3.677 & 20.579 \\
\hline Nossa Senhora Da Glória & 14.287 & 4.797 & 19.084 \\
\hline Nossa Senhora De Lourdes & 26.026 & 8.250 & 34.276 \\
\hline Poço Redondo & 3.094 & 1.089 & 4.183 \\
\hline Porto Da Folha & 32.907 & 9.928 & 42.835 \\
\hline \multicolumn{1}{c|}{ Total } & 30.416 & 6.703 & 37.119 \\
\hline
\end{tabular}

Fonte: IBGE, Censo Agropecuário, 2017. Org: Autores. 2020.

Tabela 6- Alto Sertão Sergipano - Quantidade Vendida de Leite de Vaca (em mil litros), na Agricultura Familiar e Não Familiar - 2017.

\begin{tabular}{l|c|c|c}
\hline Município & \multicolumn{3}{|c}{ Quantidade Vendida De Leite De Vaca (Mil Litros) } \\
\hline & Agricultura Familiar - Sim & Agricultura Familiar - Não & Total \\
\hline Canindé De São Francisco & 6.896 & X & 11.406 \\
\hline Gararu & 15.392 & 3.365 & 18.757 \\
\hline Monte Alegre De Sergipe & 13.483 & 4.662 & 18.145 \\
\hline Nossa Senhora Da Glória & 24.086 & 8.073 & 32.159 \\
\hline Nossa Senhora De Lourdes & 2.304 & 956 & 3.260 \\
\hline Poço Redondo & 31.472 & 9.668 & 41.140 \\
\hline Porto Da Folha & 28.515 & 6.147 & 34.662 \\
\hline
\end{tabular}

Geopauta, Vitória da Conquista ISSN: 2594-5033, V. 4, n. 3, 2020, p.(153-179) http://periodicos2.uesb.br/index.php/geo, 


\begin{tabular}{l|r} 
Total & 122.148 \\
\hline
\end{tabular}

Legenda: (x) Valor inibido para não identificar o informante.

Fonte: IBGE, Censo Agropecuário, 2017. Org: Autores. 2020.

Mapa 4- Alto Sertão Sergipano - Relação entre Estabelecimentos com presença de Leite de Vaca, Quantidade Produzida e Vendida (em mil litros) - 2017

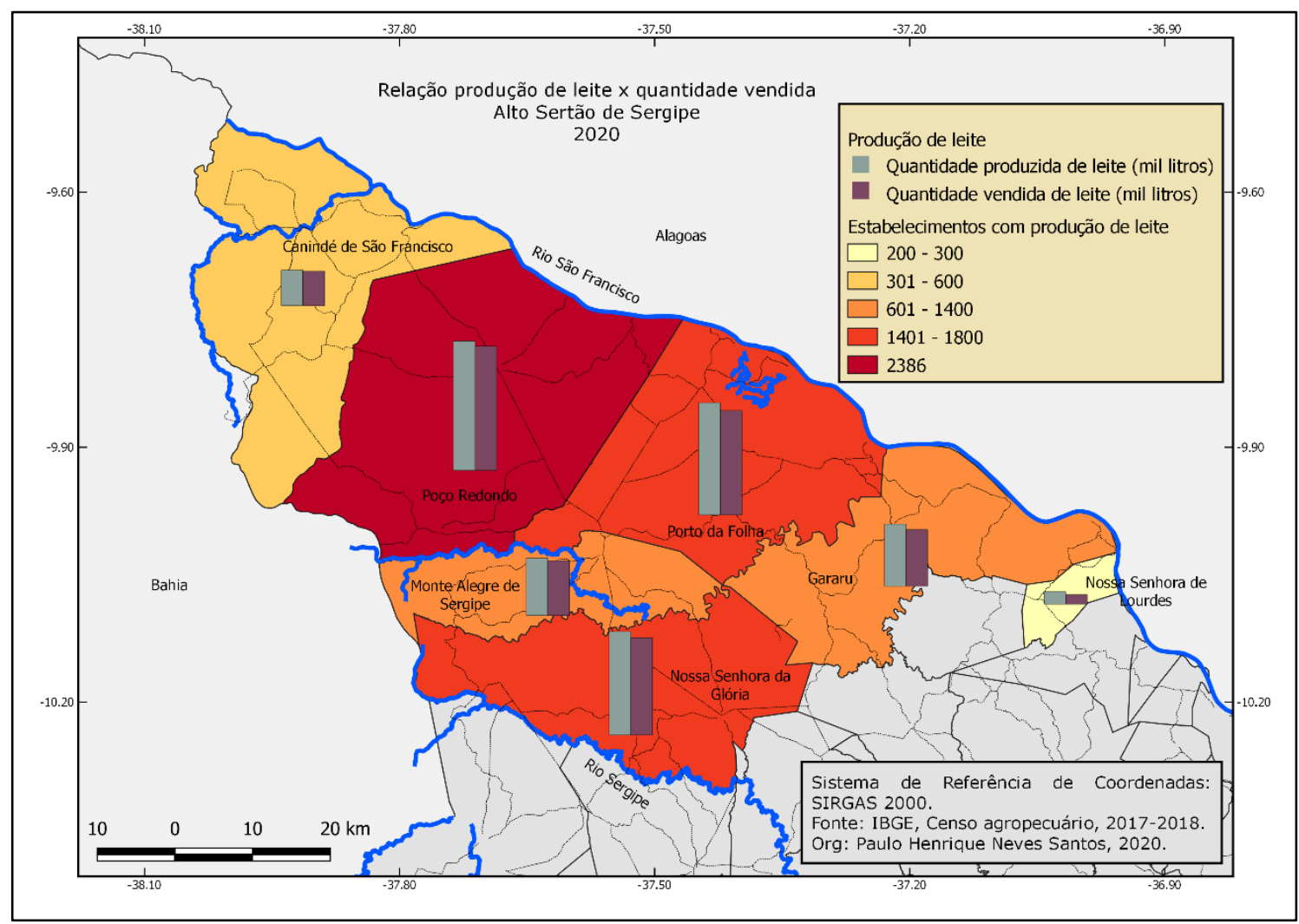

Fonte: IBGE, Censo agropecuário, 2017. Org: Autores. 2020.

Quanto a produção de lavoura temporária situa-se como segmento secundário do Alto Sertão Sergipano, apresentando números poucos expressivos, especialmente relacionado na questão dos cultivos vendidos (Tabela 7). Nota-se que grande parte da produção da lavoura temporária tem papel estratégico no autoconsumo, ou até mesmo para alimentação animal, mas sem desprezar a comercialização desses produtos.

$\mathrm{Na}$ produção de lavoura temporária destaca-se o município de Poço Redondo representando os maiores valores absolutos tanto na produção quanto na venda, exceto na produção de milho forrageiro, tendo como destaque o município de Nossa Senhora da Glória (Tabela 8 e 9).

Atrelada a palma forrageira como complementação alimentícia para o gado no alto sertão, o milho forrageiro também desempenha a mesma função, com um total de 643.471 toneladas produzidas durante o período de referência, sendo comercializado somente $3,7 \%$ desse total. 
Dentre as lavouras temporárias, a mandioca (aipim, macaxeira) destaca-se como a lavoura temporária com a maior taxa de comercialização no alto sertão, com 98,2\% do total produzido no período de referência sendo destinado para a comercialização.

Em relação a lavoura permanente a análise é limitada face a omissão de informações disponibilizada pelo próprio IBGE, onde a letra " $X$ " representando a inibição dos valores sobre a lavoura permanente, pressupõe que uma parte da produção seja feita por capital privado, pessoa jurídica ou física. Contudo, nos municípios onde os dados são disponíveis, observa-se que os valores da produção e sua respectiva comercialização apresentam números inexpressivos economicamente, quando se comparado ao quantitativo de estabelecimentos em cada município. $\mathrm{O}$ aspecto interessante dos dados das lavouras permanentes é demonstrado sua irrelevância radical: praticamente não existe essa lavoura no sertão sergipano, excetuando-se o município de Poço Redondo, em face da existência de alguns núcleos rurais irrigados (particularmente nos assentamentos), na qual permite desenvolver essas culturas. Como apresentado na Tabela 7, a quantidade produzida praticamente não tem importância nenhuma.

Tabela 7- Alto Sertão Sergipano - Quantidade Produzida e Vendida das Lavouras Temporárias e Permanentes, por Município (em ton. ou por mil frutos) - 2017.

\begin{tabular}{c|c|c|c|c}
\hline \multirow{2}{*}{ Municípios } & \multicolumn{2}{|c|}{ Lavoura Temporária } & \multicolumn{2}{c}{ Lavoura Permanente } \\
\cline { 2 - 5 } & Q. Produzida & Q. Vendida & Q. Produzida & Q. Vendida \\
\hline Canindé De São Francisco & 31.024 & 4.885 & $\mathrm{X}$ & $\mathrm{X}$ \\
\hline Gararu & 28.2093 & 5.610 & $\mathrm{X}$ & $\mathrm{X}$ \\
\hline Monte Alegre De Sergipe & 22.961 & 1.586 & - & - \\
\hline Nossa Senhora Da Glória & $\mathrm{X}$ & $\mathrm{X}$ & $\mathrm{X}$ & $\mathrm{X}$ \\
\hline Nossa Senhora De Lourdes & 5.720 & 333 & - & - \\
\hline Poço Redondo & 51.165 & 10.000 & 529 & 391 \\
\hline Porto Da Folha & 30.277 & 8.646 & 29 & 4 \\
\hline
\end{tabular}

Legenda: (x) Valor inibido para não identificar o informante. (-) Zero absoluto, não resultante de um cálculo ou arredondamento.

Nota: Devido a multiplicidade de unidades de medida possíveis de serem utilizadas na lavoura temporária e na lavoura permanente, o IBGE não define uma unidade de medida padrão quando se trata do quantitativo geral, apresentando, na tabela disponibilizada pelo Sidra, com a expressão "não se aplica".

Fonte: IBGE, Censo Agropecuário, 2017. Org: Autores. 2020.

Tabela 8- Alto Sertão Sergipano - Quantidade Produzida das principais colheitas da lavoura temporária, por município (em toneladas) - 2017.

\begin{tabular}{|c|c|c|c|c|c|c|c|}
\hline Município & $\begin{array}{l}\text { Feijão Preto } \\
\text { Em Grão }\end{array}$ & $\begin{array}{c}\text { Feijão De Cor } \\
\text { Em Grão }\end{array}$ & $\begin{array}{l}\text { Feijão Fradinho } \\
\text { Em Grão }\end{array}$ & Feijão Verde & $\begin{array}{c}\text { Mandioca } \\
\text { (Aipim, } \\
\text { Macaxeira) }\end{array}$ & $\begin{array}{l}\text { Milho Em } \\
\text { Grão }\end{array}$ & $\begin{array}{c}\text { Milho } \\
\text { Forrageiro }\end{array}$ \\
\hline $\begin{array}{c}\text { Canindé De São } \\
\text { Francisco }\end{array}$ & - & 14 & 55 & 43 & 322 & 105 & 16513 \\
\hline Gararu & - & 23 & 12 & 4 & 7 & 7429 & 65586 \\
\hline $\begin{array}{c}\text { Monte Alegre De } \\
\text { Sergipe }\end{array}$ & - & $X$ & 34 & - & - & 522 & 87618 \\
\hline $\begin{array}{c}\text { Nossa Senhora } \\
\text { Da Glória }\end{array}$ & - & 46 & 20 & 2 & $X$ & 2066 & 242488 \\
\hline $\begin{array}{c}\text { Nossa Senhora } \\
\text { De Lourdes }\end{array}$ & - & - & 0 & 4 & 28 & 640 & 23864 \\
\hline Poço Redondo & - & 96 & 168 & 158 & 4840 & 748 & 109557 \\
\hline Porto Da Folha & $x$ & 28 & 48 & 7 & 16 & 1717 & 97845 \\
\hline
\end{tabular}




\begin{tabular}{c|c|c|c|c|c|c|c|}
\hline Total & - & 207 & 337 & 218 & 5213 & 13227 & 643471 \\
\hline
\end{tabular}

Legenda: (x) Valor inibido para não identificar o informante. (-) Zero absoluto, não resultante de um cálculo ou arredondamento.

Nota: Devido a multiplicidade de unidades de medida possíveis de serem utilizadas na lavoura temporária e na lavoura permanente, o IBGE não define uma unidade de medida padrão quando se trata do quantitativo geral, apresentando, na tabela disponibilizada pelo Sidra, com a expressão "não se aplica".

Fonte: IBGE, Censo Agropecuário, 2017. Org: Autores. 2020.

Tabela 9- Alto Sertão Sergipano - Quantidade Vendida das principais colheitas da lavoura temporária, por município (em toneladas) - 2017.

\begin{tabular}{|c|c|c|c|c|c|c|c|}
\hline Município & $\begin{array}{l}\text { Feijão Preto } \\
\text { Em Grão }\end{array}$ & $\begin{array}{c}\text { Feijão De Cor } \\
\text { Em Grão }\end{array}$ & $\begin{array}{l}\text { Feijão Fradinho } \\
\text { Em Grão }\end{array}$ & $\begin{array}{l}\text { Feijão } \\
\text { Verde }\end{array}$ & $\begin{array}{c}\text { Mandioca } \\
\text { (Aipim, } \\
\text { Macaxeira) }\end{array}$ & $\begin{array}{l}\text { Milho Em } \\
\text { Grão }\end{array}$ & $\begin{array}{c}\text { Milho } \\
\text { Forrageiro }\end{array}$ \\
\hline $\begin{array}{c}\text { Canindé De São } \\
\text { Francisco }\end{array}$ & - & 0 & 50 & 41 & 311 & 48 & 365 \\
\hline Gararu & - & 1 & 0 & 2 & 3 & 1199 & 1641 \\
\hline $\begin{array}{l}\text { Monte Alegre } \\
\text { De Sergipe }\end{array}$ & - & $X$ & 6 & - & - & 30 & 4504 \\
\hline $\begin{array}{c}\text { Nossa Senhora } \\
\text { Da Glória }\end{array}$ & - & 16 & 4 & - & $X$ & 387 & 4552 \\
\hline $\begin{array}{c}\text { Nossa Senhora } \\
\text { De Lourdes }\end{array}$ & - & - & - & 0 & 4 & 37 & 336 \\
\hline Poço Redondo & - & 6 & 73 & 140 & 4790 & 198 & 5510 \\
\hline Porto Da Folha & $X$ & 2 & 4 & 1 & 12 & 1069 & 7458 \\
\hline Total & - & 25 & 137 & 184 & 5120 & 2968 & 24366 \\
\hline
\end{tabular}

Legenda: (x) Valor inibido para não identificar o informante. (-) Zero absoluto, não resultante de um cálculo ou arredondamento.

Nota: Devido a multiplicidade de unidades de medida possíveis de serem utilizadas na lavoura temporária e na lavoura permanente, o IBGE não define uma unidade de medida padrão quando se trata do quantitativo geral, apresentando, na tabela disponibilizada pelo Sidra, com a expressão "não se aplica".

Fonte: IBGE, Censo Agropecuário, 2017. Org: Autores. 2020.

Em seguida apresenta se a analise dos dados por município, para tentar alcançar uma intepretação mais real de mudanças na organização da agricultura no Território do Alto Sertão Sergipano.

\section{Poço Redondo}

No município de Poço Redondo, um dos maiores em área territorial no Território e presença de maior número de assentamentos rurais no estado de Sergipe, foram recenseados 4.077 estabelecimentos agropecuários, dos quais 3.433 estão enquadrados, na condição de produtor, como proprietário, onde $34,9 \%$ do total de estabelecimentos são classificados com área entre 0 a 5 ha, 10,2 \% do total de estabelecimentos com área entre 5 a 10 ha, 15,6\% do total de estabelecimentos com área entre 10 a 20 ha e 32,2\% do total de estabelecimentos com área entre 20 a 50 ha.

Do total de estabelecimentos, 93,1\% inserem na categoria como agricultor familiar e $6,9 \%$ como não sendo agricultor familiar. O que demonstra que a relação entre proprietário e domínio da agricultura familiar é positiva do ponto de vista de estabelecer ações de natureza 
pública (políticas governamentais) voltadas para o meio rural municipal, mas que infelizmente ainda deixa muito a desejar.

Quanto ao Uso da Terra no município, a lavoura temporária é cultivada em 937 (22,9\%) estabelecimentos agropecuários, as práticas da horticultura estão presentes em 212 (5,1\%) estabelecimentos e a lavoura permanente em apenas 105 (2,5\%) estabelecimentos. Entretanto, é na pecuária, particularmente no rebanho bovino, a principal atividade econômica rural do município, estando presente em 2.787 (68,3\%) estabelecimentos agropecuários (Gráfico 3 ).

Gráfico 3- Poço Redondo/SE - Uso da Terra, Por Estabelecimento Agropecuário (\% em relação ao Total) - 2017

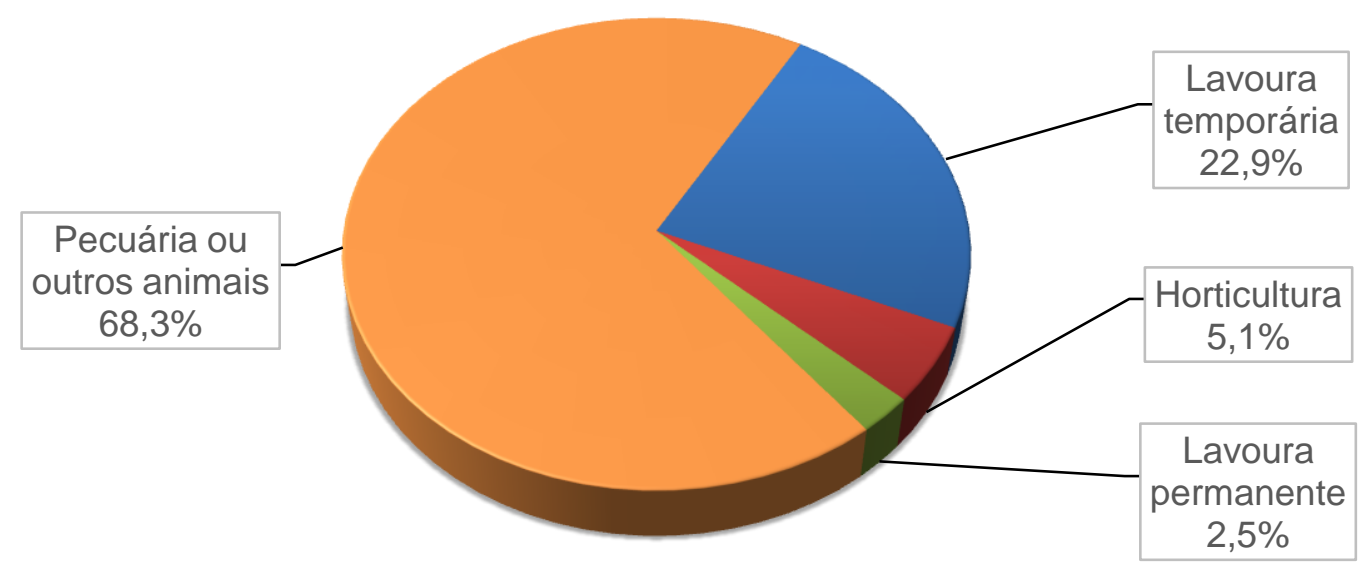

Fonte: IBGE, Censo Agropecuário, 2017. Org: Autores. 2020.

A lavoura temporária, com total de 937 estabelecimentos, dos quais $873(93,1 \%)$ são classificados como de agricultura familiar e 64 (6,9\%) como não sendo da agricultura familiar. É pertinente observar que aqueles estabelecimentos classificados de "não da agricultura familiar", presume que essas unidades não significam que seriam ao desenvolvimento do agronegócio, mais comum em outros territórios sergipanos.

A produção de feijão (de cor em grão, fradinho, verde e preto) no município totalizou apenas 422 toneladas, cultivada em uma área de 790 ha, das quais foram vendidas 219 toneladas $(51,8 \%)$, com um faturamento de 497 mil reais. A lavoura da mandioca (aipim, macaxeira) teve uma produção absoluta de 4.840 toneladas cultivada em uma área de 493 ha, das quais foram vendidas 4.790 toneladas, com faturamento bruto de 4.334 mil reais. Apesar dos indicadores apresentados em supra, relevante observar a quantidade vendida dessas culturas tradicionais, mostrando o balanceamento entre o autoconsumo e a venda em si, superando determinada narrativa em que os agricultores residentes nos territórios do semiárido (onde o 
Alto Sertão Sergipano) produzem para o autoconsumo, quase que exclusivamente, quando na verdade existe esse equilíbrio face a importância de vender parte do produto e que não seria necessariamente como complemento, mas integrando como processo socioeconômico do agricultor familiar.

A produção de lavoura temporária no município destaca-se especialmente com o milho forrageiro e a palma forrageira. O primeiro com o total de 109.557 toneladas produzidas em uma área de 7145 ha, dos quais apenas 5510 toneladas (5,0\%) foram comercializadas. Em relação a palma, foram produzidas 83.040 toneladas em uma área de 2155 ha, das quais foram vendidas 3.822 toneladas $(4,6 \%)$, contabilizando um total de faturamento de 6.946 mil reais. É a típica cultura agrícola voltada para alimentação animal, vendida tanto no território, como em outros territórios sergipanos. E o mais relevante seria sua consolidação no Alto Sertão, tendo o Poço Redondo como um dos municípios mais importantes no processo de produção.

\section{Nossa Senhora da Glória}

É o município mais importante em termos econômico-regionais do território, e nele foram recenseados 2.992 estabelecimentos agropecuários, dos quais 2.395 enquadrados na condição de produtor "proprietário", em que 39,6 \% do total de estabelecimentos são classificados com área variando de 0 a 5 ha, 14,4\% do total de estabelecimentos com área entre 5 a 10 ha, 20,2\% do total de estabelecimentos com área entre 10 a 20 ha e 18,7\% do total de estabelecimentos classificados com área entre 20 a 50 ha. O que demonstra equilíbrio na distribuição dos estabelecimentos por grupo de área, com a irrelevância dos chamados 'latifúndios', por sinal, inexistentes nos Censos de 2006 e 2017 enquanto tipologia dos estabelecimentos.

Portanto, é fantasia de determinados estudos, particularmente para o estudo da realidade no estado de Sergipe, afirmar que “existem latifúndios”, estes ainda são importantes por domínio de área (daí o Índice de Gini acima de 0,8), mas não enquadrados ao vetusto "latifúndio por dimensão", que o IBGE não mais aplica. Do total dos estabelecimentos agropecuários, 84,4\% são tipologicamente enquadrados como de agricultura familiar e 15,6\% como não sendo de agricultores familiares, enquanto a lavoura temporária foi cultivada em 638 $(21,3 \%)$ estabelecimentos e o rebanho bovino em $2.347(78,4 \%)$, isso enquanto uso da terra. Seria mais um município onde o domínio da pecuária é determinante, com quantitativo de 38.906 bovinos na data de referência, mostrando também sua vocação para uma atividade de 
maior adaptação ao meio ambiente hostil em face de irregularidade climatérica e dos ganhos de produtividade face as mudanças dos padrões alimentares do rebanho e a melhoria genética.

Pertinente observar que, em relação a atividade da pecuária em Nossa Senhora da Glória, 84,4\% dos estabelecimentos agropecuários são classificados como de agricultura familiar, mostrando a força do trabalho familiar e do desenvolvimento de uma atividade que nos últimos anos tem crescido significativamente, inclusive rebatido no dinamismo econômico do município e território, sendo o principal polo comercial e de serviços do território, bem como no crescimento urbano de sua sede municipal. Na mesma toada podemos observar no que se refere as lavouras temporárias desenvolvidas no município, onde os agricultores são os maiores responsáveis pelo desenvolvimento destas culturas (com 83\% dos estabelecimentos agropecuários), articulando enquanto uso da terra, da combinação necessária entre a pecuária enquanto atividade econômica mais relevante e as culturas temporárias, vinculando-se estas para autoconsumo familiar, com quase nula em termos de comercialização.

A produção de feijão (de cor em grão, fradinho, verde e preto) no município alcançou um total de 68 toneladas e cultivada em uma área total de 121 ha, das quais foram vendidas apenas 20 toneladas. Desse modo, essa cultura temporária caracteriza-se essencialmente como de autoconsumo, em que sua comercialização, principalmente entre os agricultores familiares, não tem valor comercial, sendo uma cultura bem tradicional no município. Quanto a palma forrageira, o município alcançou um total produzido de 86.572 toneladas, extraída em uma área cultivada de 1.471 ha, das quais foram vendidas apenas 931 toneladas, observando que a palma é estratégica para os agricultores familiares deste município, ou seja, articulando a pecuária de relativo rendimento (como a produção do leite de vaca).

O município apresenta a maior produção de milho e palma forrageira do Alto Sertão. O milho com total de 242.488 toneladas em uma área total de 1072 ha, com apenas 4.552 toneladas $(1,8 \%)$ comercializadas. Em relação a palma foram produzidas 86.572 toneladas em uma área total de 1471 ha, sendo comercializado apenas 931 toneladas (1,0\%). Apesar do baixo percentual de estabelecimentos que possuem assistência técnica no município (13\%), os elevados valores na produtividade evidenciam a utilização de tecnologias para as referidas produções no período de referência.

\section{Porto da Folha}

Em relação ao município de Porto da Folha foram garimpados 2.647 estabelecimentos agropecuários, dos quais 2.428 são proprietários, onde $28,1 \%$ do total de estabelecimentos são 
classificados com área entre 0 a 5 ha, 20,6\% do total de estabelecimentos com área entre 5 a 10 ha, $23,3 \%$ do total de estabelecimentos com área entre 10 a 20 ha e $17,6 \%$ do total de estabelecimentos com área entre 20 a 50 ha.

Do total de estabelecimentos agropecuários, a maioria estar enquadrada como de agricultura familiar com presença insignificante de estabelecimentos que desenvolvem lavouras temporárias, práticas da horticultura e cultivo de lavouras permanentes em termos de uso da terra. Registra-se que o rebanho bovino estar presente em 2.268 estabelecimentos agropecuários, consolidando a pecuária bovina como atividade mais importante do município e de domínio em termos de uso da terra (Gráfico 4).

Gráfico 4- Porto da Folha/SE - Uso da Terra nos Estabelecimentos Agropecuários (\% em relação ao total) - 2017

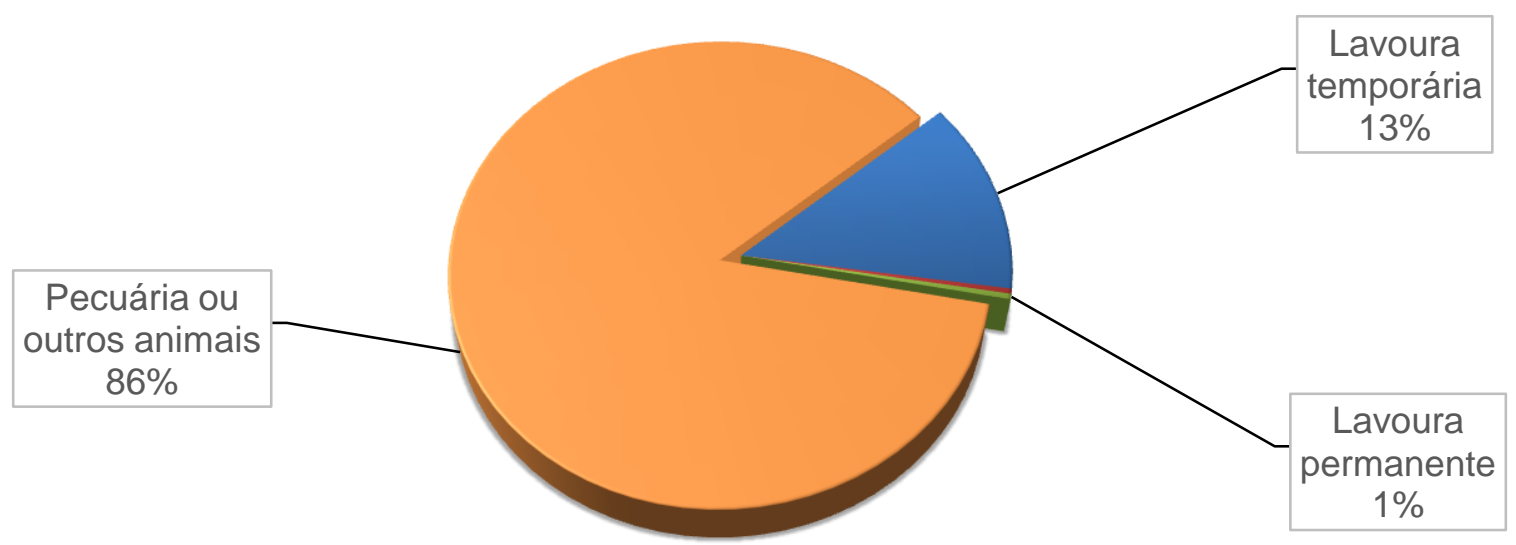

Fonte: IBGE, Censo agropecuário, 2017. Org: Autores. 2020.

Destarte, o domínio da atividade pecuarística é refletida pelo número de estabelecimentos agropecuários que desenvolvem essa importante atividade (um total de 2.268), dentre os quais $89 \%$ estão enquadrados como de agricultura familiar, focando a tradição e a importância estratégica da pecuária, em especial na presença do rebanho bovino, com um efetivo razoável (34.746 cabeças), refletindo principalmente na produção de leite de vaca (37.119 litros).

Em seguida, destaca-se as lavouras temporárias, com total de 353 estabelecimentos agropecuários, sendo $72 \%$ são enquadrados como de agricultura familiar. A produção de feijão (de cor em grão, fradinho, verde e preto) o município produziu 83 toneladas em uma área total de 150 ha, e com mais de $90 \%$ voltado para o autoconsumo, tornando a cultura temporária de maior referência na alimentação desses agricultores. No mesmo sentido, observa-se a 
insignificância da lavoura da mandioca (aipim, macaxeira) teve uma produção de apenas 16 toneladas, praticamente voltado para o autoconsumo. Mais uma questão é pertinente: praticamente a referida lavoura desapareceu no município, central na alimentação desses agricultores e isso podem ser refletidas no desaparecimento das unidades de beneficiamento da farinha de mandioca (as chamadas casas de farinha).

Em relação ao milho forrageiro, foram produzidas 97.845 toneladas em uma área total de 5.019 ha, sendo comercializadas 7.458 toneladas (7,6\%). Quanto a palma forrageira, a produção alcançou um total de 56.964 toneladas em uma área colhida de 951 ha, das quais foram vendidas apenas 1.854 toneladas (portanto, menos de 5\% do total), reafirmando que os agricultores familiares cultivam quase que exclusivamente para o autoconsumo, e para a alimentação animal.

\section{Gararu}

No município de Gararu foram coletados 2.253 estabelecimentos agropecuários, dos quais $85,7 \%$ desses estabelecimentos são proprietários das unidades familiares, onde 34,6\% do total de estabelecimentos são classificados com área entre 0 a 5 ha, 16,9\% do total de estabelecimentos com área entre 5 a 10 ha, 17,6 \% do total de estabelecimentos com área entre 10 a 20 ha e $21,4 \%$ do total de estabelecimentos com área entre 20 a 50 ha.

Do total de estabelecimentos agropecuários, $89 \%$ são classificados como de agricultura familiar, e do ponto de vista do Uso da Terra, as lavouras temporárias estão presentes apenas em 414 estabelecimentos agropecuários, é insignificante o cultivo da horticultura e a lavoura permanente praticamente não existe. O que destacaria, como os demais municípios do Território do Alto Sertão Sergipano, a pecuária ou outros animais, presentes em mais de 80\% dos estabelecimentos agropecuários, indo na mesma direção da principal atividade econômica, também estratégica para a reprodução da agricultura familiar na constituição da renda dessas famílias, além do autoconsumo das demais lavouras (Gráfico 5).

Gráfico 5- Município de Gararu/SE - Uso da Terra nos Estabelecimentos Agropecuários (\% em relação ao total) 


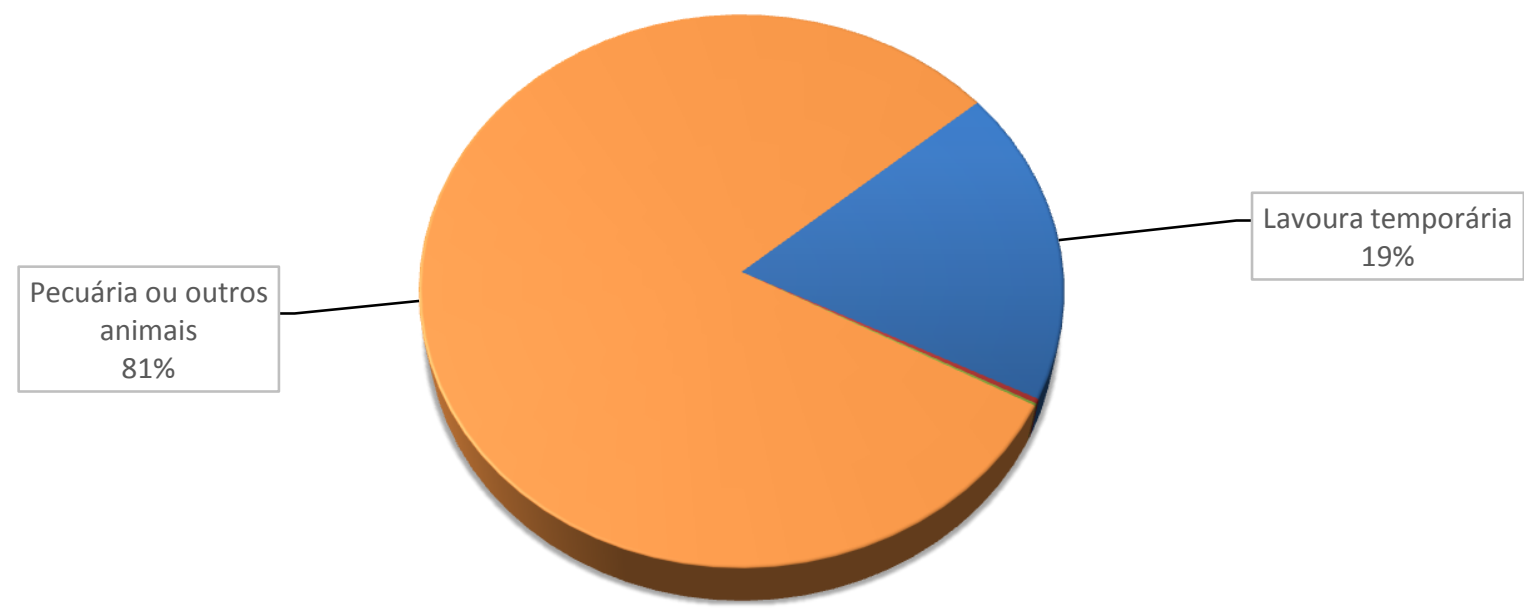

Fonte: IBGE, Censo agropecuário, 2017. Org: Autores. 2020.

No município foram constatados 25.947 bovinos nos estabelecimentos agropecuários, dando uma média de 14 cabeças por estabelecimento, o que oferece uma média aritmética razoável, particularmente entre os agricultores familiares, com natural consequência no desenvolvimento da produção do leite de vaca no município, com produção de 20.579 litros.

Quanto a lavoura temporária, apenas 22,8\% dos estabelecimentos agropecuários desenvolvem essa atividade, estando mais concentrados nas unidades consideradas como de agricultura familiar, praticamente toda ela voltada para o autoconsumo, destacando a cultura do feijão e a tradicional cultura da mandioca, com produção irrelevante, e que confirma a decadência das lavouras temporárias, e mais ainda, a lavoura permanente foi extinta; alterando substancialmente da esperada diversificação da agricultura familiar no município, dando-lhe um caráter monótono no sistema de produção, baseando-se na criação do rebanho bovino e no desenvolvimento da cultura forrageira com uso da palma como fonte de alimento desse rebanho. Da produção da palma, 90,2\% foi destinada basicamente ao consumo destes animais no município. Sobre o milho forrageiro, foram produzidos 65.586 toneladas em uma área total de 3622 ha, sendo comercializadas 1.641 toneladas $(2,5 \%)$.

\section{Canindé de São Francisco}

Os municípios possuíram 1.229 estabelecimentos agropecuários, dos quais 74,4\% são proprietários enquanto condição do produtor dominante, e por grupos de área, onde $17,4 \%$ do total de estabelecimentos são classificados com área entre 0 a 5 ha, 12,1\% do total de estabelecimentos com área entre 5 a 10 ha, 24,3\% do total de estabelecimentos com área entre 10 a 20 ha e $37,4 \%$ do total de estabelecimentos com área entre 20 a 50 ha. 
Gráfico 6- Município de Canindé do São Francisco/SE: Uso da Terra nos Estabelecimentos Agropecuários (\% em relação ao total) - 2017

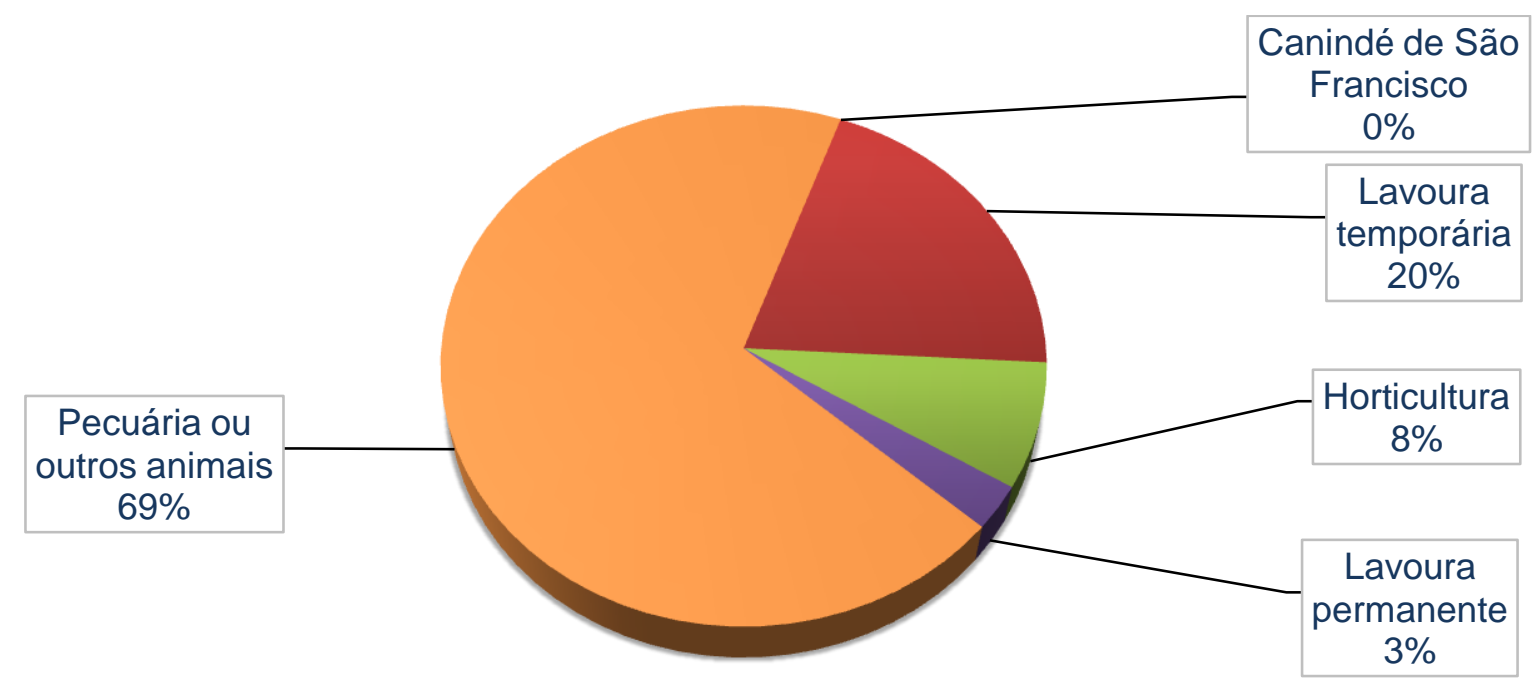

Fonte: IBGE, Censo agropecuário, 2017. Org: Autores. 2020.

Do total de estabelecimentos agropecuários, $90 \%$ são classificados como de agricultura familiar Em termos de uso da terra, o cultivo da lavoura temporária é desenvolvida em apenas $20,2 \%$ dos estabelecimentos agropecuários, horticultura em 7,7\%, e a lavoura permanente em 2,8\% desses estabelecimentos. Quanto ao rebanho bovino, seria mais um município onde as atividades rurais estão mais concentradas, presentes em 68,7\% dos estabelecimentos (Gráfico 6)

No município foram encontrados nos estabelecimentos agropecuários um rebanho bovino 18.372 cabeças, dando uma média de 15 cabeças por unidade e esse número razoável vincula-se não apenas na produção de leite de vaca, mas também na produção de carne bovina. Como existe domínio das unidades da agricultura familiar, o rebanho médio pode ser um indicador positivo na constituição da renda familiar desses agricultores.

Em seguida, destacam-se as lavouras temporárias, presentes em 20,1\% dos estabelecimentos agropecuários, em sua maioria cultivadas em unidades gestadas pelo agricultor familiar, podendo estar relacionada a existência de áreas de irrigação com apoio institucional do Estado, na medida em que se caracteriza como território de forte escassez hídrica. Dessas culturas, destaca-se a cultura do feijão, e importante, sua produção não estaria voltada quase que exclusivamente para o autoconsumo, como na maioria dos municípios do 
território, quando $81,2 \%$ da produção foi destinada à comercializada, inclusive com ganhos de produtividade face ao apoio da irrigação de baixo custo.

Na mesma linha dos municípios do território, destaca-se a cultura da mandioca, também fortemente comercializada $(93,7 \%$ do total da produção), também vinculada as práticas da concessão sem ônus da irrigação, e de certa forma, beneficiando os agricultores familiares. Por outro lado, a palma forrageira vincula-se a atividade da pecuária sem confinamento, voltada quase que exclusivamente ao consumo dos rebanhos. A comercialização dessa cultura temporária representou apenas $8,7 \%$ do total da produção. Acompanhado pelo milho forrageiro com 16.513 toneladas produzidas, com comercialização somente de 365 toneladas $(2,2 \%)$.

\section{Monte Alegre de Sergipe}

No município de Monte Alegre foram encontrados 1.162 estabelecimentos agropecuários, dos quais 83,9\%, na condição de produtor, como proprietários, onde 21,6 \% do total de estabelecimentos são classificados com área entre 0 a 5 ha, 17,9\% do total de estabelecimentos com área entre 5 a 10 ha, 31,0\% do total de estabelecimentos com área entre 10 a 20 ha e 18,6 \% do total de estabelecimentos com área entre 20 a 50 ha.

Ainda para reforçar os estabelecimentos de gestão familiar, $91 \%$ foram enquadrados como de agricultura familiar. Quanto ao uso da terra, o município concentra-se praticamente no desenvolvimento da pecuária de baixo rendimento, as lavouras tem pouca expressão, ou seja, a agricultura, em termos gerais, praticamente não é desenvolvida no município, mostrando a fragilidade.

A atividade da pecuária, basicamente extensiva, é desenvolvida em mais de $90 \%$ dos estabelecimentos agropecuários, e destes, $89 \%$ estão enquadrados como agricultores familiares, tendo em média 16 cabeças por estabelecimento, reforçando a vocação do município na atividade da pecuária, tanto na produção do leite (19.084 litros), como também da carne bovina, destinada para os mercados periódicos do território.

As culturas temporárias são inexpressivas, presentes em apenas 8,9\% dos estabelecimentos, tendo como principal cultura o feijão, praticamente toda ela voltada ao autoconsumo, não havendo, em seu todo, diversificação da produção familiar, revelando um quadro agrícola fragilizado em que combina, para o autoconsumo, a produção do leite e a cultura do feijão, sendo aquela a base na constituição da renda familiar. Em relação a palma forrageira, parte significativa é comercializada, o que torna contraditória na medida em que a pecuária bovina é a atividade rural mais importante do município e fundamentalmente a palma 
tem papel estratégico na alimentação do rebanho bovino. Foram produzidas 78 toneladas de palma forrageira, com comercialização de 56 toneladas $(71,7 \%)$. Em contraste, o milho forrageiro foi produzido 87.618 toneladas, com comercialização de 4504 toneladas $(5,1 \%)$.

\section{Nossa Senhora de Lourdes}

No município de Nossa Senhora de Lourdes foram garimpados apenas 396 minguados estabelecimentos agropecuários, dos quais $93,7 \%$ são considerados proprietários destas unidades, onde 48,7 \% do total de estabelecimentos são classificados com área entre 0 a 5 ha, 15,6\% do total de estabelecimentos com área entre 5 a 10 ha, 15,4 \% do total de estabelecimentos com área entre 10 a 20 ha e 12,8\% do total de estabelecimentos com área entre 20 a 50 ha.

Destes estabelecimentos, $85 \%$ foram enquadrados como de agricultura familiar e o que demonstra, como os demais municípios do território, que a agricultura familiar tem importante papel no desenvolvimento da agricultura, mesmo apresentando indicadores econômicos inexpressivos, e a atividade relevante vincula-se com a pecuária, particularmente com a pecuária bovina de baixo ganhos de produtividade, tanto na produção de leite, como da carne bovina, mas, que, combinado com os inexpressivos cultivos temporários, integram o uso efetivo da terra no município

Existe predomínio da pecuária no município, atividade desenvolvida em 85,1\% dos estabelecimentos agropecuários, indicador fundamental e de longa tradição no território, apesar do pequeno quantitativo quando se comparado aos municípios vizinhos. No município haviam 5.352 cabeças de bovinos e a produção de leite alcançou a produção absoluta de 4.183 litros.

Quanto a lavoura temporária, mais de $80 \%$ foram cultivadas em unidades da agricultura familiar, onde culturas como a do feijão foram produzidas exclusivamente para o autoconsumo das famílias, apresentando, infelizmente, uma produção insignificante, mostrando um quadro preocupante, inclusive da possibilidade de diminuição das unidades familiares e da perda da importância da agricultura familiar no município e possivelmente em todos os municípios do Território do Alto Sertão Sergipano. Em seguida destaca-se a cultura da mandioca, matéria prima no beneficiamento da farinha, $85,7 \%$ da produção destinou-se ao consumo da família. Em relação a palma forrageira, a questão do autoconsumo também é expressiva, quando 98,4\% da produção teve como fim esse modelo de consumo. Já o milho forrageiro, foi produzido 23.864 toneladas, com comercialização de apenas 336 toneladas $(1,4 \%)$. 


\section{Considerações finais}

Os dados e indicadores do Censo Agropecuário 2017 são uma importante fonte de dados sobre o cenário do mundo rural brasileiro. Apesar das barreiras inerentes à metodologia de qualquer processo de caráter declaratório, as informações disponibilizadas permitem aos formuladores de políticas públicas e de estudiosos identificarem as características e o perfil de um mundo complexo e heterogêneo como é o mundo rural.

Destarte, o Alto Sertão Sergipano, apesar de suas características climáticas, essa questão não seria relevante em entender o quadro não muito positivo do meio rural neste território, na medida em que, pelos dados e informações publicados, o segmento apresenta problemas de natureza estrutural e com perspectivas relativamente negativas, em face de uma tendência de baixa produtividade e de rendimentos decrescentes das unidades produtivas, principalmente as familiares.

A falta de integração entre os produtores que não possuem individualmente capital para investimentos nas suas propriedades cria um abismo entre o potencial comercio com união dos pequenos produtores na forma de cooperativas e a competição capitalista, que favorece os grandes produtores ou empresas privadas, devido a taxação dos produtos com os menores valores possíveis.

Desse modo, são dois desafios e com diferentes destinos. O primeiro relaciona-se com a possibilidade de "desaparecimento da agricultura familiar" pela incapacidade de acompanhar as inovações e as mutações permanentes nos processos de comercialização, além da questão do baixo nível organizativo dos agricultores familiares. O segundo, pela inserção, mesmo que recentes, do padrão alimentar dos rebanhos aí presentes e do melhoramento genético dos mesmos, com possibilidade de ganhos de produtividade. Esses são os quadros que abrem para o Território do Alto Sertão Sergipano daqui para frente.

\section{Referências}

AGROPECUÁRIO, IBGE Censo. Instituto Brasileiro de Geografia e Estatística, 2017.

ARAÚJO, Hélio Mário de. Clima e Condições meteorológicas. SANTOS, Vera Maria dos. Geografia de Sergipe. São Cristóvão: Universidade Federal de Sergipe, CESAD, 2012.

BRASIL, Lei. 11.326, de 24 de Julho de 2006. Estabelece as diretrizes para formulação da política nacional da agricultura familiar e empreendimento familiares rurais, Diário Oficial da União-Seção, p. 1-25, 2006. 
CAMARGOS, L. R.; GOIS, R. M.; NÓBREGA, W. Anuário Socioeconômico de Sergipe. Grupo de Pesquisa em Análise de Dados Econômicos. Departamento de Economia da Universidade Federal de Sergipe. Ano, p. 2526-895, 2017.

DELGROSSI, M.E. Algoritmo para delimitação da agricultura familiar no censo agropecuário 2017, visando a inclusão de variável no banco de dados do censo, disponível para ampla consulta. Ministério da Agricultura, Pecuária e Abastecimento. Brasília. Disponível em < https://sidra.ibge.gov.br/Content/Documentos/CA/Metodologia\%20Agricultura\%20familiar\%2 0(IBGE)\%20DelGrossi\%20final\%205jun2019.pdf>. Acesso em : 10/04/2020.

DOS SANTOS LIMA, Elder. Contribuições teóricas sobre os principais sistemas meteorológicos em sergipe. Revista geonorte, v. 3, n. 8, p. 502-514-502-514, 2012.

MUÑOZ, A.M; PINTO, A. F; NASCIMENTO, C.G. Plano de desenvolvimento regional do estado de Sergipe. Editora IABS, Brasília-DF, Brasil - 2017. 